\title{
L. GEBRYN-BAYDI
}

Department of Aerospace Geodesy, National Aviation University, 1, Kosmonavta Komarova Ave., Kyiv, Ukraine, 03058, tel.: 063-338-51-35, e-mail: liliya.gebrinbaydi@gmail.com

\section{APPLICATION OF REMOTE SENSING METHODS TO EVALUATION OF SOIL FERTILITY INDICATORS OF ZAKARPATTIA LANDS}

\author{
https://doi.org/10.23939/istcgcap2017.01.042
}

Aim. Identification and evaluation of the soil fertility indicators based on processing of the data of on-ground and remote sensing research on the agricultural lands of different landscape zones in Zakarpattia. Methodology. The proposed methodology of the laws of physics that describe the relation between the content of humus in soil and spectral energy brightness of soil which is interpreted based on multi-spectral aerospace images, includes three research approaches. The first approach refers to research and identification of statistical linear dependencies of the actual humus level in soil and the spectral energy brightness of soil which was obtained based on processing of the multi-spectral aerospace images. The second approach lies in developing new models that are based on linear dependencies of the actual humus level in soil and the spectral energy brightness of soil and infrared electromagnetic of electromagnetic emission. The third approach is founded on application of degree models that in the best manner describe such dependence. From the point of view of mathematics, importance of the three stages was validated using identification of significance for the correlation coefficients, confidence intervals, mean square deviations of the calculated humus level indicator from the actual humus level indicator, and application of the Fisher coefficient. Findings. In the course of identification and research of statistical linear dependencies of spectral brightness of channels and the relevant humus level indicators in soil it was investigated that the closest inverse linear dependence was detected in the red (Red) spectral channel of the visible range. In application of the second approach, it was revealed that to identify and evaluate the humus level in soil the model which mediates the red and infrared spectral channels based on the relation of the close infrared channel to the red channel, is the most appropriate. As a result of trial of the third approach it was determined that application of power law model includes only the red spectral channel. Scientific novelty. It was stated that using the data on remote sensing of the Earth to identify and evaluate the quantitative indicators of humus level content in soil in the landscape areas of Zakarpattia it is most appropriate to apply the models designed based on the data on spectral energy brightness in the visible and infrared spectral ranges, since the mean square deviation of the estimated humus content level in soil from the actual humus level indicator in these models is minimal, whereas the probability is the highest. Practical significance. This approach enables quick and reliable collection of information on the quantitative indicators of the humus level content in soil for rational managerial decision-making on applicability agrotechnical means to for prevention of soil fertility reduction in relation to landscape zones of Zakarpattia.

Key words: remote sensing of Earth; spectral energy brightness; spectral indices; multi-spectral aerospace images; monitoring of ground layers; humus; linear mathematical models.

\section{Introduction}

In the course of studying current problems of ground layers monitoring in Ukraine [Panas R. M., 2013] and its individual regions, in our case in Zakarpattia [Hebryn L. V., 2015], it was revealed that application of the international experience to improvement of the existing system in Ukraine is one of the methods for improvement of the current state of agricultural lands. Since the most significant qualitative and quantitative variable of agricultural lands is soil fertility. Humus level content in soil is the major indicator of soil fertility, so qualitative and quantitative evaluation is essential for ground monitoring and argotechnical means for sustaining and recovery of soil fertility [Medviediev V. V., 2002]. Agrochemical method of evaluating the special location of humus level is quite long, costly, and a labor-intensive process. Therefore, to solve this problem it is proposed to use the findings of aerospace research in combination with selective choice of soil samples to identify the humus level content [Shatokhin A. V., 2001; Achasov V. A., 2008; Sakhatskyi O. I., 2008].

To prove the hypothesis on connection of the percent indicator of humus level with spectral brightness of channels it is necessary to investigate the degree of statistical dependence of spectral energy brightness of ground and humus level in soil 
and to estimate the significance of this connection [Sakhatskyi O. I., 2008].

Although visual decoding of aerospace images gives information about the objects, the main parameters that enable classifying soils from other objects and performing quantitative decoding of humus level in soil by space images are the brightness in specific spectral channels with relevant wave length. Fig. 1 shows spectral profiles of: soils with different humus levels, plants, and water. It was observed that the spectral brightness of soil with humus level of $0,55 \%$ and $3.41 \%$ differ by absorption intensity in the visible range of $0.45-0.68 \mathrm{mkm}(2,3,4)$ and infrared red range of $0.84-2.3 \mathrm{mkm}(5,6,7)$. Therefore, soils that are more concentrated with humus which renders them the dark color are characterized by low spectral brightness, whereas the soils with lower humus level content exhibit a higher level of spectral brightness. This serves evidence of the inverse relationship between the humus level and spectral brightness of soil.

Currently, several methods of modeling humus level in soil that are based on linear, non-linear and multiple regressions are known [Malashevskyi V. A., 2013]. In particular, in papers by V. Achasov and D. Bidolakh, who investigated the relationship between the humus level and brightness of the ground layer of soil using space images and defined the rigid anticorrelation that was connected with the brightness values in the red section of the image range. The correlation ration was equal to $\mathrm{R}=-0.74$ [Achasov V. A., 2008]. A. Shatokhin and M. Lyndin researched the typical humus, identified fixed relationship $(\mathrm{R}=-0.94)$ between the humus level and brightness in the near-infrared channel [Shatokhin A. V., 2001]. Using the data on space imaging Landsat 7 within the test sections of Chernihiv and Khmelnytsk oblasts, O. Sakhatskyi presented the results of investigation on statistical data processing which revealed the linear dependence of the spectral data pixels in the red channel $(R=-0.95)$ and the near- infrared channel $(\mathrm{R}=-0.85)$ and in the blue channel $(\mathrm{R}=-0.81)$ with the average humus level indicator [Sakhatskyi O. I., 2008]. S. Truskavetskyi researched the ground layer on the fields of Zhytomyr Polissya using the multi-spectral aerospace scanning with the help of SPOT satellite and specified that the relationship between the humus level content in soil and spectral brightness is significant in the green channel $(R=-0.88)$, in the red channel $(R=-0.88)$, and in the near-infrared channel $(R=-0.90)$ [Truskavetskyi S. R., 2006].

While studying the soils of Krasnodar Krai with the help of satellite images of Spot 5, the researchers offerred multiple linear models with visible and near-infrared range $(\mathrm{R}=-0.74)$ [Malashevskyi V. A., 2013]. In the course of study of dark brown soils of Mykolayiv oblast, S.G. Chornyi suggested using the parabolic model which rests upon the relation of red and nearinfrared channels ( $R=-0.63$ ) [Chornyi S. G., 2012], and as approximately similar values of correlation coefficients for the relationship between humus level and the values of brightness for all three spectral channels (green, red, and near-infrared) were obtained, the equation for the multiple regression model was offered $(\mathrm{R}=0.53)$ [Chornyi S. G., 2016].

The special condition in identification and evaluation of humus levels based on the data of aerospace and ground research is that the studied fields should be characterized by the following indicators: air-dried state of soil [Schmugge T., 1980], absence of skin, the size of the particles of soil (rigidity) should not exceed $2 \mathrm{~cm}$ [South S., 2004], complete or partial absence of green or dry plants or its remnants, absence of colored particles in soil (iron compounds) [Gorbane G., 2008].

While performing research on spectral characteristics of soil and analyzing the scientific literature, it can be concluded that in the visible $(R G B)$ and near-infrared (NIR) area of the electromagnetic spectrum the brightness of soil is connected with an increase or decrease in humus concentration in soil.

An acute and important task is usage of several methods of investigation, for example using a combination of ground and satellite surveys with the purpose of their operational comparison and obtaining the relevant level of valid results. 


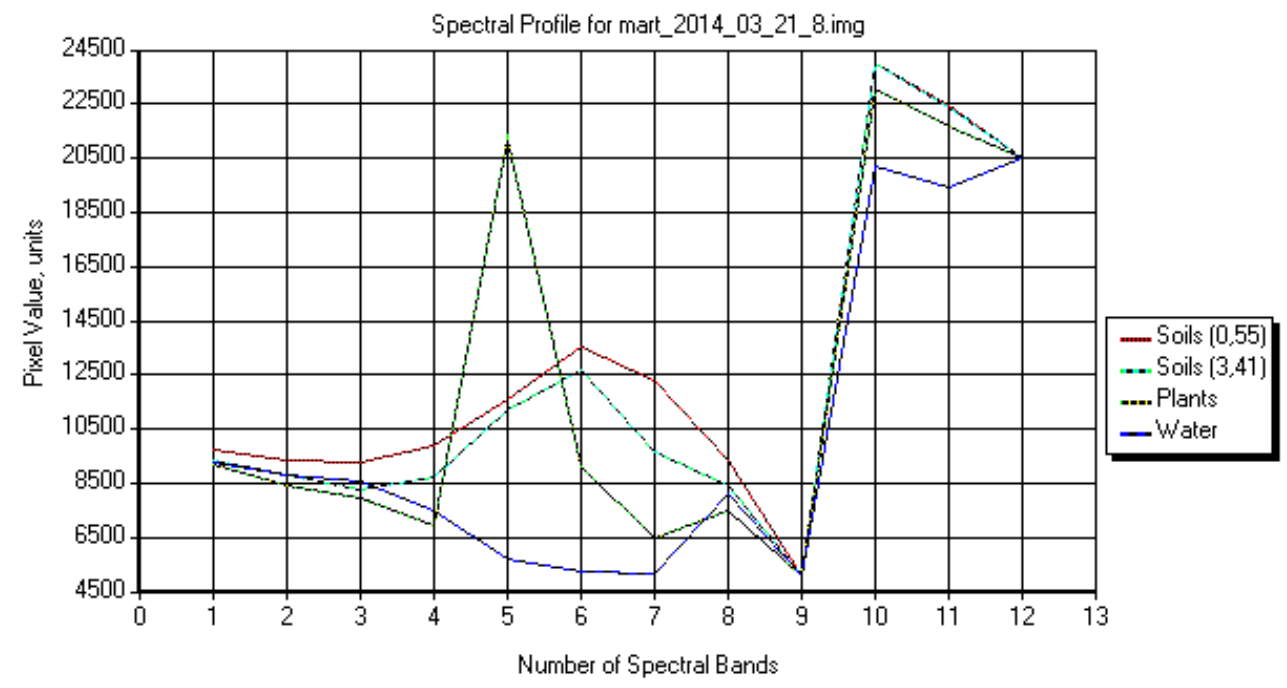

Fig. 1. Spectral profiles of soil, plants, and water according to Landsat 8 OLI

\section{Aim}

Identification and evaluation of the soil fertility indicators based on processing of the data from onground and remote sensing research on the agricultural lands of different landscape zones in Zakarpattia, Ukraine.

\section{Methodology}

To identify and evaluate the quantitative indicators of humus content in soil using the findings of processing the multi-spectral images. The methodology is based on study of humus content dynamics, soil content, and other characteristics of soil was employed. Thus the main subject of investigation is soil. [Sakhatskyi O. I., 2008].

The methodology of investigation comprises three main approaches:

1. Application of statistical linear regression dependence that in the course of adaptation take the following expression [Sakhatskyi O. I., 2008; Hebryn L. V., 2015]:

$$
B_{n}=a G_{a c t}+b,
$$

where $B-$ is energy brightness of soil in the relevant spectral channel, $n$ - spectral channel: red, blue, green, infrared; $a$ and $b$ - numerical parameters of the model; $G_{a c t}-$ percent indicator of humus level.

2. Linear combinations of brightness and spectral indices that rest on utilization of channels which identify the effect from plants and humidity on spectral brightnesses of soil were used.
3. Power law models for identification and evaluation of the humus level content of soil indicators were emplyed.

Evaluation of humus content level in soil was based on the data from aerospace and ground research under the conditions of various landscape areas of the region suggests the following stages [Gebrin L. V., 2015]:

- obtaining statistical data which describe the fertility indicators of soils in the region and preliminary analysis of every field. In the given case, the data on the humus level content in soil $\left(G_{a c t}\right)$ with a breakdown into monitored sections (MS), and agrochemical land classification of the agricultural lands, in the regions and landscape areas for the year 2013 [Bandurovych Yu. Yu., 2014];

- downloading of the available aerospace images for the period under study with minimal cloud cover. For the given study 5 multi-spectral aerospace images were obtained from 8 OLI satellite ( 5 scenes), for the territory of Zakarpattia oblast with minimal cloud cover from 0 to $5 \%$ in spring season (March, April) and fall season (September, October, November) of 2013 which fully meet the requirements of the investigation process. Satellite images were downloaded from the official web-site glovis.usgs.gov;

- includes preliminary processing of the images. Formation of synthesized multi-spectral aerospace image was carried out. Radiometric correction of images was performed further. Its 
essence lies in converting raw data (digital numbers) into physical units by way of transforming them into real values of spectral energy brightness using special formulas. To perform these calculations, it is necessary to know the initial scaling factors. The general formula of the algorithm of radiometric calibration of satellite images Landsat 8 OLI is expressed as (2):

$$
L_{\lambda}=M_{l} Q_{c a l}+A_{l},
$$

where $L_{\lambda}$ - spectral energy brightness is $\left(\mathrm{W} / \mathrm{m}^{2} \mathrm{sr} \mu \mathrm{m}\right)$, $M_{l}$ - multiplicative (RADIANCE_MULT_ BAND) and $A_{l}$ - additional (RADIANCE_ADD_ BAND) are ratios of scaling for brightness of the individual channel from metadata, $Q_{c a l}$ - raw pixel data (digital numbers) [Zanter K., 2016].

The following stage was for performing atmospheric corrections for the aerospace images. Atmosphere can influence on the values of brightness that are registered by the imaging system in two ways: by dispersion and absorption of the energy from electromagnetic waves. In performing atmospheric correction, characteristics of standard atmosphere are used. These characteristics enable obtaining approximate results. There are two methods of accounting for the influence of atmospheric conditions: based on the program algorithms and on estimation of vegetation indices [Burshtynska Kh. V., 2013]. In the given case, the module Atcor 3 of the software package Erdas Imagine was used which implemented the method of program algorithms by rendering the objects with their ratios of spectral brightness, deleting the atmospheric haze, and topographically normalizing the images. This method is rational for the sections that are located in the near-mountain and mountain landscape areas [Richter R., 2016]. Preliminary processing and further calculations of the obtained satellite images were performed in a specialized program Erdas Imagine 2013;

- calculation of the vegetation index according to the brightness indicators of the relevant spectral channels. Vegetation indices are estimated based on the physical and chemical phenomena from obtaining aerospace images and statistical data. Currently, approximately 500 different vegetation indices are known. In the article [Burshtynska Kh. V., Badysh V., 2014] 30 vegetation indices are systematized against the main indicators which include: sensitivity to vegetation, influence of the ground line, and atmosphere. To solve the problem of separating the open soil from vegetation, the vegetation index NDVI was applied. In the suggested classification, the given indicator belongs to class $I$ and is interpreted though such characteristics like the very noticeable influence of the plant litter (3):

$$
N D V I=\frac{N I R-R E D}{N I R+R E D}
$$

where NIR and RED refer to the values of spectral energy brightness of the relevant pixels on the image that are obtained in the red (RED) visible and near-infrared (NIR) specter sections.

Average values of the vegetation index NDVI are calculated on the basis of pixel data that were accounted for in the sample as a result of establishing of ring since the area of the section is equal to 2500 square meters.

- obtaining average values of spectral brightness in the selected channels in accordance with the sections where soil samples were taken. Relevant to the coordinates of the sections a selection of pixels was performed in a way that the established area $\left(S_{p}\right)$ as a result of forming of the highlighted ring which was close to the area under study, (2500), and the average values of spectral brightness of the selected channels could be identified (Blue, Green, Red, NIR, SWIR1, SWIR2) [Richards J., 2006].

In order to conduct research according to the first approach the following activities were performed: the linear dependence of indicators of the actual humus level in soil $G_{a c t}$ and the average indicators of spectral brightness of the selected channels in the identified sample of pixels was stated. Correlation coefficients $R$ and determination ratios $R^{2}$ were calculated, confidence intervals were estimated, as well as the significance of correlation coefficients under the confidence probability 0.95 and significance level 0.05 [Gmurman V. E., 2003]. Graphs of dependence of the average indicators of spectral brightness of the selected channels in the identified sample of pixels and the actual humus level content in soil indicator $G_{a c t}$ were constructed. The most rigid linear dependence characterized by the highest correlation coefficients $R$, and the acceptable confidence intervals and significance of 
the correlation coefficient were defined. Calculation of the humus level content $G_{p n}$ based on the inverse linear regression equation (4) is:

$$
G_{p n}=B_{n}\left(\frac{1}{a}\right)-\left(\frac{b}{a}\right) .
$$

Evaluation of the accuracy of findings and calculation of standard deviation $\sigma$ (5) for the constructed indicator of humus level content $G_{p n}$ from the actual $G_{a c t}$ was carried out:

$$
\sigma=\sqrt{\frac{\sum\left(G_{a c t}-G_{p n}\right)^{2}}{n-2}} .
$$

While applying the second approach the results of the investigation were used which show that the spectral brightness of soil is influenced by the presence of vegetation that is calculated based on the vegetation index NDVI (3), however, in the given study the relation of brightnesses NIR/Red was used, and by presence of extra humidity that is estimated by spectral indices with the help of the relation of near and short-wave infrared channel [Gao B., 1996], green and near-infrared channel, and green and first short-wave infrared channel [Sakhatskyi O.I., 2009]. After the first approach was applied and it was reported that the most rigid correlation of humus level content has the intensity of the reflected and absorbed emission in red and infrared areas, so these two channels were included in the initial model. Thus, the general model becomes 2.1. (6):

$$
\begin{gathered}
G_{p n}=a \operatorname{Re} d+b N I R+c \frac{N I R}{\operatorname{Re} d}+ \\
+d \frac{\text { Green }}{N I R}+u \frac{\text { Green }}{\text { SWIR } 1}+f \frac{N I R}{S W I R 1}+g
\end{gathered} .
$$

To employ the third approach for identification and evaluation of the humus content for a soil indicator the power law model is proposed. The model is constructed based on the physical relationship that includes the effect from different parameters in the spectral brightness of soil. In the initial expression it is formulated as (7):

$$
\text { 3.1. } G_{p n}=G_{0} \text { Blue }^{a} \text { Green }^{b} \operatorname{Re} d^{c} \text { NIR }^{d} \operatorname{SWIR}^{u} \operatorname{SWIR}^{f}
$$

The main criterion of evaluating the precision is the standard deviation of the estimated humus level content $\left(G_{p n}\right)$ from the actual humus level indicator $\left(G_{a c t}\right)$, and the Fisher criterion (F-criterion). Application of F-criterion does not characterize the specific model. The F-criterion only compares two models. Therefore, estimation of confidence probability according to the Fisher criterion, the essential condition is identifying what model the comparison was carried out against. Using the method of calculating the confidence probability it can be validated on which level of confidence the hypothesis is correct and on which level of confidence the hypothesis is rejected. Thus, with not so high confidence, the probability for the difference between models it can be asserted that the models describe the experimental data in a similar way, so there is no necessity to use a more complicated model. Therefore, the maximum simplification of the model is carried out, until only the most significant parameters are retained. This type of model is called optimal.

\section{Findings and evaluation of the proposed methodology}

Based on the findings of the first approach application of the statistical linear relationship of spectral brightness of pixels on the sections under study, and the relevant indicators of humus level in soil, it was stated that the most rigid inverse linear dependence (3) was observed in the red (Red) spectral channel of the visible range (Fig. 2) with the following results obtained after mathematical processing by the average indicators for the sample: correlation coefficient $R=-0.72$, confidence interval ${ }_{r 1}=-0.81 ; r_{2}=-0.58$, significance of correlation coefficient $t=|4.28|>2.00_{73 ; 0.05}$, with standard deviation (4) of the estimated humus level content indicator ( $G p n$ ) from the actual humus level content indicator (Gact) $\sigma=0.821 \%$ (Fig. 3).

Reversed linear dependence is found between data in blue: $R=-0.57, r 1=-0.78 ; r 2=-0.38$, $t=|3.04|>2.00_{73 ; 0.05}, \quad \sigma=1.5 \%$ and the green: $R=-0.57,{ }_{r l}=-0.78 ;_{r 2}=-0.38, t=|3.04|>2.00_{73 ; 0.05}$, $\sigma=1.26 \%$ spectral channels. In the near-IR range (NIR) linear dependence is observed at level $R=-0.36,{ }_{r l}=-0.54 ; r_{2}=0.15, t=|1.74|<2.00_{73 ; 0.05}$, $\sigma=2.48 \%$. As for shortwave infrared channels (SWIR 1): $R=-0.23, r 1=-0.44 ; r_{2}=0.01$, $t=|1.10|<2.00_{73 ; 0.05}, \sigma=11.99 \%$ and (SWIR 2): $R=-0.27, r 1=-0.47 ; r 2=0.05, t=|1.28|<2.00_{73 ; 0.05}$, $\sigma=10.89 \%$ at $p=0.95$ and $\alpha=0.05$, the dependence is not significant, this fact indicates partial noise in these channels. That is why these 
channels in given conditions, at first approach, is not recommended for linear determination of humus content in soil. However, in second and third approaches there is a possibility to apply these channels, because they are responsible for determinating soil covering moisture.

Given calculated data are averaged selectively, which consist of information obtained during treatment of five multispectral images of Landsat 8 OLI for 2013.
In the second approach of the proposed methodology model 2.1 was considered and applied (6). Since the determining factor of this model was the account of vegetation and moisture in the research areas that could influence the obtained results, the model was checked by several interpretations in order to define how much influence and significance one or another parameter of the model had on the results obtained (Table 1, Fig. 4).

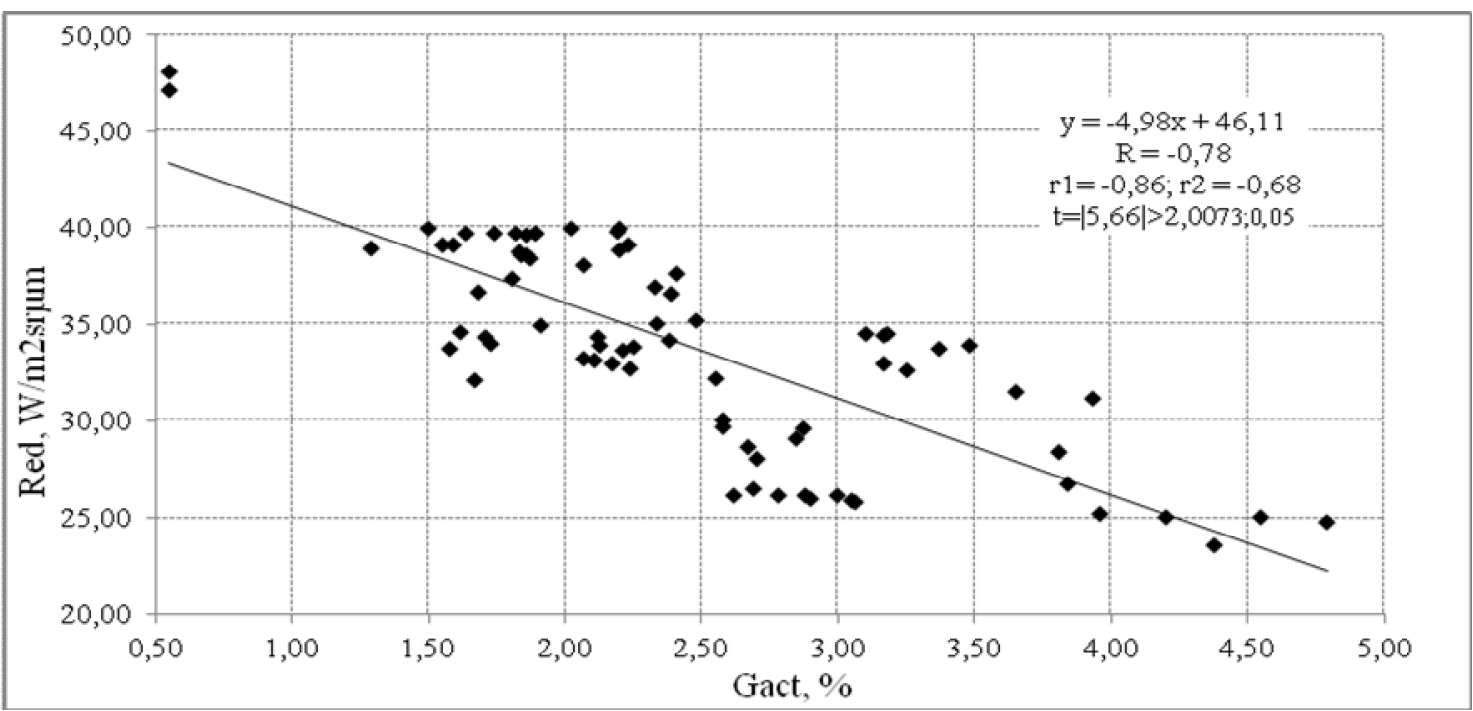

Fig. 2. Linear statistical dependence of Gact and the spectral brightness in the Red channel (08.03.2013) Landsat 8 OLI

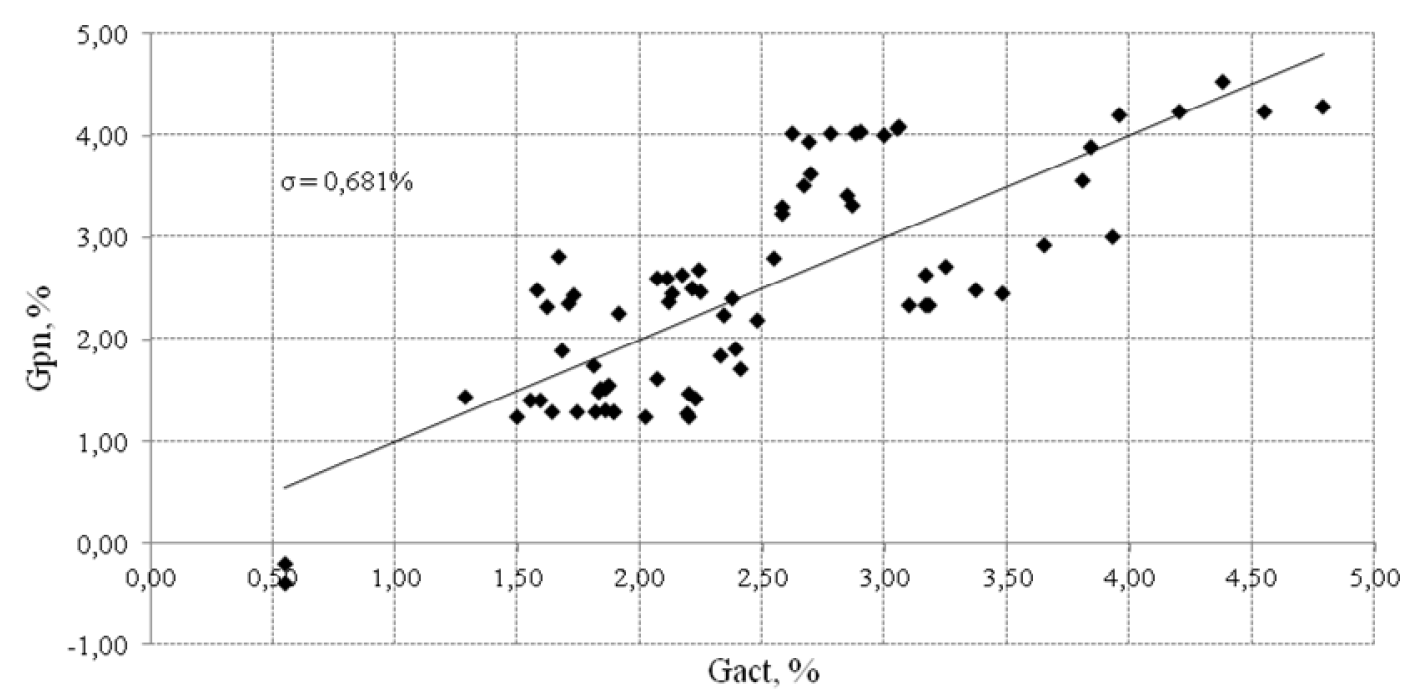

Fig. 3. Graphical representation of standard deviation $\sigma$ of the estimated humus level indicator $G_{p n}$ on the actual $G_{a c t}$ from the data of the red channel (08.03.2013) 


\section{Determination of adequacy of the models linear combinations of brightness and spectral indices}

\begin{tabular}{|c|c|c|c|}
\hline № & Model & $\sigma, \%$ & $\begin{array}{c}\text { F-criterion, } \\
\%\end{array}$ \\
\hline 2.1 & $G_{p n}=a \operatorname{Re} d+b N I R+c \frac{N I R}{\operatorname{Re} d}+d \frac{\text { Green }}{N I R}+u \frac{\text { Green }}{\text { SWIR } 1}+f \frac{\text { NIR }}{S W I R 1}+g$ & $0.468_{68}$ & - \\
\hline 2.2 & $G_{p n}=a \operatorname{Re} d+b \frac{\text { Green }}{N I R}+c \frac{N I R}{\operatorname{Re} d}+d \frac{\text { NIR }}{S W I R}+u \frac{\text { Green }}{S W I R}+f$ & $0.483_{69}$ & 97.798 \\
\hline 2.3 & $G_{p n}=a \operatorname{Re} d+b N I R+c \frac{\text { Green }}{N I R}+d \frac{N I R}{S W I R}+u \frac{\text { Green }}{S W I R}+f$ & $0.503_{69}$ & 99.894 \\
\hline 2.4 & $G_{p n}=a N I R+b \frac{\text { Green }}{N I R}+c \frac{N I R}{\operatorname{Re} d}+d \frac{\text { NIR }}{S W I R}+u \frac{\text { Green }}{S W I R}+f$ & $0.470_{69}$ & 78.850 \\
\hline 2.5 & $G_{p n}=a \operatorname{Re} d+b N I R+c \frac{N I R}{\operatorname{Re} d}+d \frac{\text { Green }}{\text { SWIR } 1}+u \frac{N I R}{S W I R 1}+f$ & $0.470_{69}$ & 78.850 \\
\hline 2.6 & $G_{p n}=a \operatorname{Re} d+b N I R+c \frac{\text { NIR }}{\operatorname{Re} d}+d \frac{\text { Green }}{\text { SWIR } 1}+u$ & $0.486_{70}$ & 97.133 \\
\hline 2.7 & $G_{p n}=a \operatorname{Re} d+b N I R+c \frac{N I R}{\operatorname{Re} d}+d \frac{\text { Green }}{N I R}+u \frac{N I R}{S W I R l}+f$ & $0.468_{69}$ & 67.914 \\
\hline 2.8 & $G_{p n}=a \frac{N I R}{\operatorname{Re} d}+b \frac{\text { Green }}{N I R}+c \frac{\text { Green }}{S W I R 1}+d \frac{N I R}{S W I R 1}+u$ & $0.566_{70}$ & 99.999 \\
\hline 2.9 & $G_{p n}=a \operatorname{Re} d+b \frac{\text { Green }}{\text { NIR }}+c \frac{\text { Green }}{\text { SWIR } 1}+d \frac{\text { NIR }}{\text { SWIR } 1}+u$ & $0.526_{70}$ & 99.986 \\
\hline 2.10 & $G_{p n}=a \operatorname{Re} d+b N I R+c \frac{N I R}{\operatorname{Re} d}+d$ & $0.493_{71}$ & 91.537 \\
\hline 2.11 & $G_{p n}=a N I R+b \frac{N I R}{\operatorname{Re} d}+c$ & $0.496_{72}$ & 82.522 \\
\hline 2.12 & $G_{p n}=a \operatorname{Re} d+b \frac{N I R}{\operatorname{Re} d}+c$ & $0.512_{72}$ & 98.805 \\
\hline 2.13 & $G_{p n}=a \operatorname{Re} d+b N I R+c$ & $0.524_{72}$ & 99.804 \\
\hline
\end{tabular}

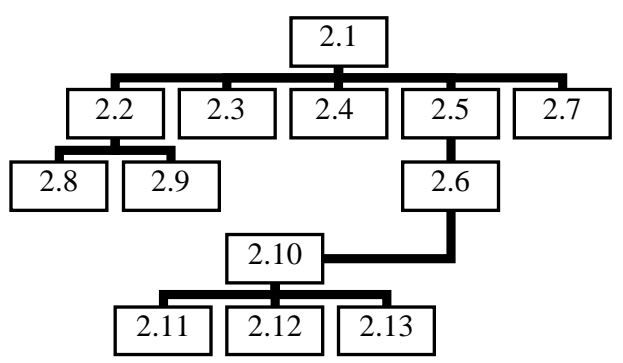

Fig. 4. Scheme of the formulas simplification sequence, 2.1-2.13 - model number

As a result of mathematical treatment of models with a set level of significance $0.003(3 \sigma)$ and confidence probability $99.7 \%$, that during the simplification process of model 2.2 to model 2.8, application of red and near-IR channels is significant with a confidence probability of $99.99 \%$. After simplification to model 2.9, application of spectral index with relation to near-IR channel to red channel is significant with a confidence probability of $99.98 \%$. Such a tendency is observed during a simplification of model 2.1 to model 2.3. Confidence probability of this spectral index is $99.89 \%$. As a result of simplification of model 2.10 to models $2.11,2.12$, and 2.13 , and also after further investigating the most significant model parameters, it was reported that application of spectral index NIR/Red is significant with a confidence probability of $99.80 \%$, and the significance of the application of a near-IR channel is defined with confidence probability $98.81 \%$. Although during application of this channel in the first approach, the mean coefficient of correlation is only $R-0.36$. This fact is explained by possible noise in the channel due to the influence of vegetation. Accordly the results of the second approach is thought identification and evaluation of quantitative indices of the humus content after spectral characteristics of proposed model 2.11 (Fig. 5): 


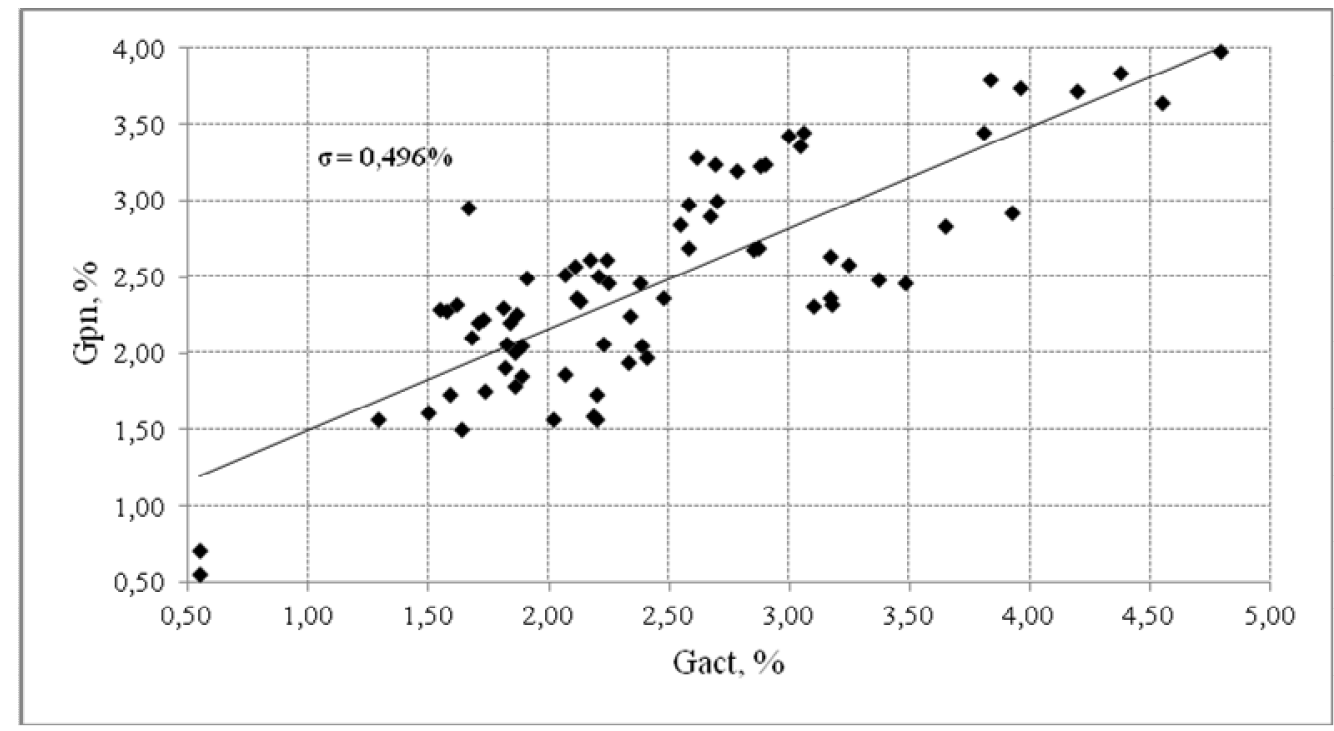

Fig. 5. Standard deviation of $\left(G_{p n}\right)$ from $\left(G_{a c t}\right)$. Model 2.11

Table 2

Determinating the adequacy of power law models

\begin{tabular}{|c|c|c|c|}
\hline № & Model & $\sigma, \%$ & F-criteria,\% \\
\hline 3.1 & $G_{p n}=G_{0}$ Blue $^{a}$ Green $^{b} \operatorname{Re} d^{c}$ NIR $^{d}$ SWIR $^{u}$ SWIR2 $^{f}$ & $0.465_{68}$ & - \\
\hline 3.2 & $G_{p n}=G_{0}$ Blue $^{a}$ Green $^{b} \operatorname{Re} d^{c}$ NIR $^{d}$ & $0.469_{70}$ & 95.464 \\
\hline 3.3 & $G_{p n}=G_{0}$ Green $^{a} \operatorname{Re} d^{b}$ NIR $^{c}$ & $0.495_{71}$ & 96.226 \\
\hline 3.4 & $G_{p n}=G_{0}$ Green $^{a} \operatorname{Re}^{b}$ & $0.508_{72}$ & 96.226 \\
\hline 3.5 & $G_{p n}=G_{0}$ Green $^{a} N I R^{b}$ & $0.710_{72}$ & $\mathbf{9 9 . 9 9 9}$ \\
\hline 3.6 & $G_{p n}=G_{0} \operatorname{Re} d^{a} N I R^{b}$ & $0.508_{72}$ & $\mathbf{9 8 . 4 6 2}$ \\
\hline 3.7 & $G_{p n}=G_{0} \operatorname{Re} d^{a}$ & $0.541_{73}$ & 95.464 \\
\hline
\end{tabular}

In the third approach, the power law model was researched for the determination and evaluation of quantitative indices of the humus content in soil according to data of Earth remote sensing and ground investigations. Based on this model application next results were obtained (Table 2).

As a result of mathematical treatment (Table 2) and simplification (Fig. 6) of proposed power law models with the set significance level $0.003(3 \sigma)$ and confidence probability of $99.7 \%$, it was found that the best variant to apply is the power law model 3.7. for determining and evaluating the quantitative indices of the humus content in soil, which used the red spectral channel with a confidence probability of $99.99 \%$.

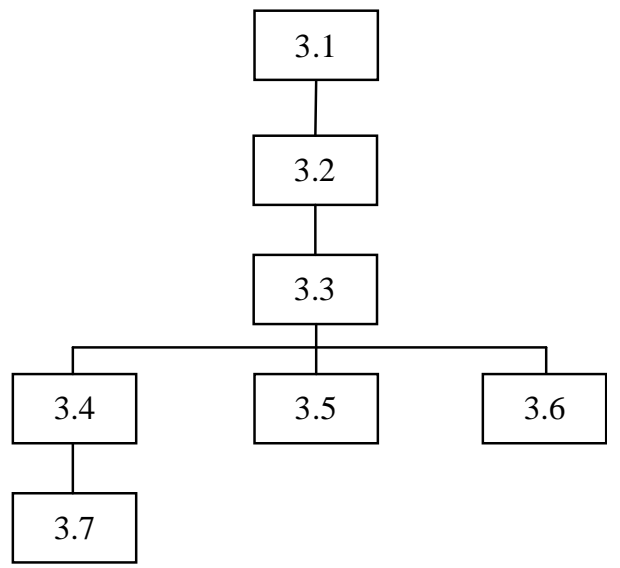

Fig. 6. The scheme of formulas simplification sequence, 3.1-3.7- model number 


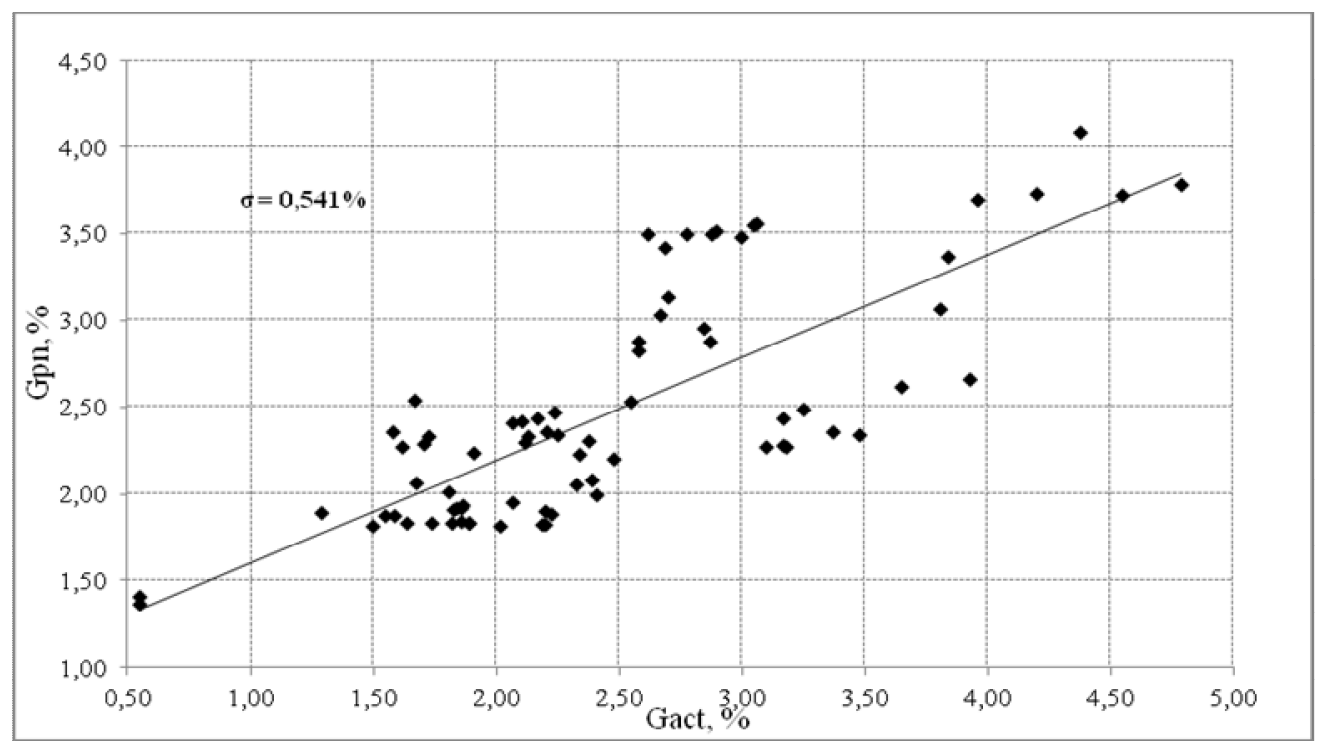

Fig. 7. Standard deviation of $\left(G_{p n}\right)$ from $\left(G_{a c t}\right)$. Model 3.7

Having analyzed models in all three approaches it is reasonable to find the most optimal model according to the methodology proposed. Application of Fisher criteria in this case is impossible, because the models are not partial cases from one another. As follows, it is possible to find the most optimal model by comparing the standard deviation $\sigma$ of the models proposed. The standard deviation of the evaluated index of humus content $\left(G_{p n}\right)$ from actual $\left(G_{a c t}\right)$ according to the model (1) with the use of red channel equal to $\sigma=0.821 \%$, with the use of near-IR channel is $\sigma=2.482$ $\%$, according to the model $2.11 \sigma=0.496 \%$, according to power law model $3.7 \sigma=0.541 \%$. This data indicates the efficiency of applying the proposed models according to the second and third approaches of proposed methodology.

\section{Scientific novelty and practical significance}

For the first time methodology for determination and evaluation of quantitative indices of the humus content in soil for agricultural lands of various Zakarpattia landscape zones was used. Methodology consists of three different approaches is based on data application from Earth remote sensing and ground investigations. It was investigated that the best models to be applied are such models which are built on the use of data of spectral radiance in the red and infrared specter ranges because of the significance of their application in these ranges are defined with confidence probability of $99.99 \%$. Standard deviation for the evaluated index of humus content from actual is minimal in these models.

The given approach provides quick and reliable information acquisition about quantitative indices of humus content in soil for making rational managing decisions concerning application of appropriate agricultural means to prevent soil fertility reduction in various Zakarpattia landscape zones.

\section{Conclusions}

As a result of applying the proposed methodology concerning determination and evaluation of quantitative indices of the humus content in soil according to data from Earth remote sensing and ground investigation, the following conclusions are made:

1. There is an existence of a reverse linear dependence between the actual index of humus content in soil and the spectral brightness of soil which is displayed in the space images investigated. Applying the given methodology, quantitative indices of humus content in soil were defined, based on statistical linear regressive dependencies between the actual index of humus content and the data of brightness of the chosen spectral channels.

2. New models of humus content dependencies of channel brightness and spectral indices of visible and infrared range of electromagnetic emission are proposed. It was investigated that the red and nearIR channels are significant with a probability of $99.99 \%$. The proposed model for determinating and evaluating indices of humus content uses the 
near-IR channel with confidence probability of $98.81 \%$ and for spectral index NIR/Red with a confidence probability of $99.80 \%$. During the research of power law models the best model to apply was found. This model used the red spectral channel with a confidence probability of $99.99 \%$.

3. The most optimal model found was 2.11 . by means of comparing standard deviations of the proposed models.

\section{REFERENCES}

Achasov V. A., Bidolakh D. I. Ispolzovaniye materialov kosmicheskoy i nazemnoy tsifrovoy fotosyemok dlya opredeleniya soderzhaniya gumusa $v$ pochvakh. [The use of material from space and digital photography to determine the content of humus in soils]. Pochvovedeniye [Soil Science]. 2008, no. 3, pp. 280-286.

Bandurovych Yu.Yu. Zvit pro vykonannya proektnotekhnolohichnykh ta naukovo-doslidnykh robit $u$ 2013 rotsi; za red. Yu. Yu. Bandurovycha [Report on performance of design, technological and research works in 2013 for ed. Bandurovch]. Uzhorod.: "Karpaty", 2014, 91 p.

Bardysh B., Burtynska Kh. Vykorystannya vehetatsiynykh indeksiv dlya identyfikatsiyi obyektiv zemnoyi poverkhni [Using vegetation indices to identify objects on the earth surface]. Suchasni dosyahnennya heodezychnoyi nauky ta vyrobnytstva [Modern achievements in geodetic science and industry]. 2014, issue 2, pp. 82-88.

Burtynska Kh. V., Dolynska I. V. Vplyv atmosfery na kosmichne zobrazhennya ta pryntsypy yiyi vrakhuvannya [The influence of the atmosphere on the space image and the principles of its consideration] Heodeziya, kartohrafiya $i$ aerofotoznimannya [Geodesy, Cartography and Aerial Photography]. Lviv, 2013, issue 78, pp. 89-96.

Chornyy S. H., Abramov D. A. Vykorystannya suputnykovykh znimkiv Landsat 7 dlya monitorynhu humusnoho stanu temno-kashtanovykh hruntiv [Using satellite images of Landsat 7 to monitoring the humus state of dark soils]. Visnyk ahrarnoyi nauky Prychornomorya [Bulletin of the Agrarian Science of the Black Sea Region]. 2012, issue 3, pp. 113-118.

Chornyy S. H., Abramov D. A. Monitorynh vmistu humusu u chorniozemi pivdennomu z vykorystannyam bahato spektralnykh znimkiv suputnyka Landsat: prostorovi ta tymchasovi aspekty [Monitoring of humus content in south chernozem using satellite spectral images of Landsat: spatial and temporal aspects]. Hruntoznavstvo [Soil Science]. 2016, Vol. 17, no. 1-2, pp. 2-30.

Gao B. C. NDWI. A normalize d differenc e water index for remote sensing of vegetatio $n$ liquid water from space. Remote Sensing of Environment. 1996, no. 58 , pp. $257-266$.
Gebrin L. V., Zeleznyak O. O., Velikodsk y Y. I., Bandurovi ch Y. Y. Comprehen sive technique for constitut ion estimatio $n$ based on satellite observati on methods. Proceedin'gs of the National Avation Universit y. 2015, no. 3 (64), pp. 91-97.

Gebrin L. V., Sakhatskyi O. I Zastosuvannya danykh dystantsiynykh aerokosmichnykh metodiv dlya uzahalnenoi otsinky stanu hruntiv rehionu [Application of remote sensing data for overall assessment of region soils]. Heoinformatyka [Geoinformatica]. 2015, issue. no. 3 (55), PP. 68-76.

Gorbane G., Raclbt D., Jacob F., Albergelj J., Andrieux P. Remote sensing of soil surface character istics from a multiscal'e classific ation approach [text]. Gorbane. CATENA, 2008, no. 75, Issue 3, pp. 308-318.

Gmurman V. Ye. Teoriya veroyatnosti $i$ matematicheskaya statistika [Probability theory and mathematical statistics]. Moscow: Vyssh.shk., 2003, 479 p.

Malyshevskiy V. A., Fedulov Yu. P., Ostrovskiy H. V. i dr. Raschet soderzhaniya gumusu s ispol'zovaniyem dannykh distantsionnogo zondirovaniya [Humus content calculation the method with use of remote sensing of the earth]. Nauchnyy zhurnal KubGAU [Proceedin'gs of the Kuban State Agrarian University]. 2013, no. 92(08), pp. 671-681.

Medvedev V. V. Monitoring pochv Ukrainy. Kontseptsiya, predvaritel'nyye rezul'taty, zadachi Monitoring of soil in Ukraine. Concept, preliminary results, tasks]. Kharkov: Antikva, 2002, 428 p.

Panas R. M., Malanchuk M. Suchasni problemy zdiysnennya monitorynhu gruntovoho pokryvu Ukrayiny [The modern problems of monitoring of the soil cover of Ukraine]. Heodeziya, kartohrafiya i aerofotoznimannya [Geodesy, Cartography and Aerial Photography]. Lviv, 2013, no..78, pp. 201-206.

Richter R., Schlapfer D. Atmospheric and topographic correction for satellite imagery (Atcor-2/3 users guide version 9.0.2). Switzerland: DLR IB, 2016, $263 \mathrm{p}$.

Richards J. A., Jia X. Remote Sensing Digital Image Analysis. Berlin: Springer-Verlag, 2006, 439 p.

Sakhatskyy O. I. Dosvid vykorystannya suputnykovykh danykh dlya otsinky stanu gruntiv $z$ metoyu rozvyazannya pryrodoresursnykh zadach [The experience using satellite data to assess the state of the soil in order to solve the nature of the problem]. Dopovidi Natsionalnoyi akademiyi nauk Ukrayiny [Reports of the National Academy of Sciences of Ukraine]. 2008, no. 3, pp. 109-115.

Sakhatskyy O. I. Metolohiya vykorystannya materialiv bahatospektralnoyi kosmichnoyi zyomky dlya vyrishennya hidroheolohichnykh zadach: avtoref. dys. na zdobuttya nauk. stupenya dokt. heol. nauk: spets. 05.07.12 "Dystantsiyni aerokosmichni doslidzhennya" [The methodologist using of material in a multifaceted space survey to solve the hydrogeological problems. Author's abstract. dis for 
obtaining sciences. degree doc. geol. Sciences: special 07.05.12 "Remote aerospace exploration"]. Kyiv, 2009, 40 p.

Sadeghi M., S. Jons, W. Philpot. A linear physically based model for remote sensing of soil moisture using short wave infrared bands. Remote Sensing of Environme nt, 2015, no. 164, pp. 66-76.

Serbin G., S. Craig, E. Raymond, B. James. Effects of soil composition and mineralogy on remote sensing of crop residue cover. Remote Sensing of Environme nt, 2009, no. 113, pp. 224-238.

South S., J. Qi, D. P. Lusch. Optimal classific ation methods for mapping agricultu ral tillage practices. Remote Sensing of Environme nt, 2004, no. 91, pp. 90-97.

Schmugge T. Microwave remote sensing of soil hydraulic properties. Soil hydrology, Land use and Agriculture. 2011, no. 19, pp. 415-421.
Shatokhin A. V., Lyndin M. A. Sopryazhennoye izucheniye chernozemov Donbassa nazemnymi $i$ distantsionnymi metodami [The study of chernozem in the Donets basin and by remote methods]. Pochvovedenie [Soil Science]. 2001, no. 9, pp. 1037-1044.

Truskavetskyy S. R. Vykorystannya bahatospektralnoho kosmichnoho skanuvannya ta heoinformatsiynykh system $u$ doslidzhenni hryntovoho pokryvu Polissya Ukrainy: avtoref. dys. na zdobuttya nauk. stupenya kand.s.-h. nauk: spets. 03.00.18 "Hruntoznavstvo" [The use of multicompetitive space for scanning and geoinformation systems in the exploration of soil coverings of the Polissya of Ukraine: author's abstract. dis for obtaining sciences. Degree Candidate s.-g. Sciences: special 03.00.18 “Soil Science"] Kh., 2006, 24 p.

Zanter K. Landsat 8 (L8) data users handbook. Version 2.0. Eros. Sioux Falls, South Dakota, 2016, 98 p.

\section{Л. ГЕБРИН-БАЙДИ}

Кафедра аерокосмічної геодезії, Національний авіаційний університет, пр. Космонавта Комарова, 1, Київ, Україна, 03058, тел.: 063-338-51-35, ел. пошта: liliya.gebrinbaydi@ gmail.com

\section{ЗАСТОСУВАННЯ МЕТОДІВ ДИСТАНЦІЙНОГО ЗОНДУВАННЯ ЗЕМЛІ ДЛЯ ОЦІНЮВАННЯ ПОКАЗНИКІВ РОДЮЧОСТІ ЗЕМЕЛЬ ЗАКАРПАТТЯ}

Мета. Застосування математичних моделей для визначення та оцінювання показників родючості грунтів на землях сільськогосподарського призначення Закарпаття на основі опрацювання даних дистанційного зондування Землі та інформації наземних досліджень. Методика. Запропонована методика, враховує фізичні закони, що описують зв'язок між кількістю вмісту гумусу у грунті та спектральною енергетичною яскравістю грунту, яка інтерпретується на мультиспектральних космічних знімках, містить три підходи дослідження. Перший підхід полягає у дослідженні та встановленні статистичних лінійних регресійних залежностей між фактичним показником вмісту гумусу в грунті, який отримано на основі наземних досліджень, та спектральною енергетичною яскравістю грунту, яку отримано в результаті опрацювання мультиспектральних космічних знімків. Другий підхід полягає у розробленні нових моделей, що побудовані на лінійній залежності вмісту гумусу від яскравостей каналів та спектральних індексів видимого та інфрачервоного діапазону електромагнітного випромінювання. Третій підхід основується на застосуванні степеневих моделей, що найкраще описують таку залежність. 3 математичної точки зору, значущість всіх трьох етапів перевірялася на основі визначення та значущості коефіцієнтів кореляції, довірчих інтервалів, середнього квадратичного відхилення обчисленого показника вмісту гумусу в грунті від фактичного та застосування критерію Фішера. Результати. У результаті встановлення та дослідження статистичних лінійних регресійних залежностей між спектральними яскравостями каналів та відповідними показниками вмісту гумусу в грунті досліджено, що найтісніша обернена лінійна залежність виявлена у червоному (Red) спектральному каналі видимого діапазону. Під час другого підходу дослідження встановлено, що найкраще застосовувати для визначення та оцінювання вмісту гумусу у грунті моделі, що використовують червоний та інфрачервоний спектральний канали та спектральний індекс на основі відношення ближнього інфрачервоного каналу до червоного. Наукова новизна. На основі застосування даних дистанційного зондування Землі виявлено, що найкраще використовувати для визначення та оцінювання кількісних показників вмісту гумусу в грунті для різних ландшафтних зон Закарпаття моделі, що побудовані на застосуванні цих спектральної енергетичної яскравості у видимому та інфрачервоному діапазонах спектра, оскільки середнє квадратичне відхилення обчисленого показника вмісту гумусу від фактичного $\epsilon$ в цих моделях мінімальним, а ймовірність $\epsilon$ максимальною. Практична значущість. Такий підхід дає змогу оперативно та достовірно отримувати інформацію про кількісні показники вмісту гумусу в грунті для прийняття раціональних управлінських рішень щодо застосування доцільних агротехнічних заходів для запобігання зниження родючості грунтів відповідно до ландшафтних зон Закарпаття.

Ключові слова: дистанційне зондування Землі; спектральна енергетична яскравість; спектральні індекси; мультиспектральні космічні знімки; моніторинг грунтового покриву; гумус; лінійні математичні моделі

Received 07.03.2017 